\title{
GEOCHEMISTRY OF SCHISTS OF NORTHWEST OBUDU PLATEAU, SOUTHEASTERN NIGERIA
}

YOUNG EZENWA OBIOHA AND BARTH N. EKWUEME

(Received 11 October 2012; Revision Accepted 29 November 2012)

\begin{abstract}
Precambrian, highly foliated, fine - medium grained schists, which comprise migmatitic schist (MS), quartz mica schist (QMS), biotite mica schist (BMS) and hornblende biotite schist (HBS) constitute important lithological unit in Northwest Obudu Plateau. The schists are associated with gneisses, amphibolites and metaquartzites, and variously intruded by granites, pegmatites and quartzo-feldspathic veins. Sedimentary rocks, which are mostly Cretaceous sandstones, flank the western margin of the study area. Modal analysis shows that all the schists are enriched in quartz, plagioclase $\left(\mathrm{An}_{32}\right)$, biotite and garnet, except the HBS which is relatively depleted in quartz but highly enriched in biotite $(25 \mathrm{vol} . \%)$ and hornblende (55 vol. \%). Sillimanite and epidote occur in accessory amounts. The co-existence of quartz- plagioclase $\left(\mathrm{An}_{32}\right)$ - garnet-biotite- muscovite- sillimanite in the MS assemblage indicates that the Schists are derivatives of metamorphism of pelitic and mafic rocks, which had attained the uppermost amphibolite facies grade. Geochemically, the schists are enriched in $\mathrm{SiO}_{2}$, which ranges from $60.11 \mathrm{wt} \%$ in the HBS, rising to $62.94 \mathrm{wt} \%$ in the $\mathrm{BMS}$ and $66.58 \mathrm{wt} \%$ in the QMS, with average of $64.56 \mathrm{wt} \%$. The high $\mathrm{SiO}_{2}$ content points to a probable effect of an intruding granitic magma on the Pan - African schists. The $\mathrm{Al}_{2} \mathrm{O}_{3}, \mathrm{Fe}_{2} \mathrm{O}_{3}, \mathrm{MgO}, \mathrm{CaO}$ and alkalies are relatively moderate to high. The samples are quartz normative, have high molecular value of $\mathrm{Al}_{2} \mathrm{O}_{3}>\{\mathrm{CaO}$ $+\mathrm{Na}_{2} \mathrm{O}+\mathrm{K}_{2} \mathrm{O}$. Plots in chemical discrimination diagrams confirm the peraluminous characteristics of the schist and suggest pelitic rock protolith except for the HBS.
\end{abstract}

KEY WORDS: Petrochemistry, Obudu Plateau, Protolith, Metapelite, Precambrian, Uppermost Amphibolite Facies

\section{INTRODUCTION}

Schist belts constitute one of the important petrological units in the Nigerian Basement Complex. They are subordinate only to the migmatitic and granite gneisses (Ekwueme, 2010). These very important rock suites occur in the Obudu Plateau of Southeastern Nigeria. Schist occurrences in the Northwest Obudu area had not been adequately documented and published. This has been mainly due to geographical problems related to rugged topography. The pioneer work on the petrography and major element geochemistry of northern Obudu was done by Ejimofor et al., (1996). Other detailed study on the adjacent blocks of the Obudu Plateau are those of Orajaka (1971), Beltaro (1962), Ekwueme (1998), Ukaegbu (2003), Ukaegbu and Beka (2007), Ephraim (2005, 2009), Ephraim et al., (2008), Ukwang (2007), Ekwueme (2010) and Obioha and Ekwueme (2011). However, these works were more generalized and not concentrated on the schists occurrences in the area. The present study is aimed at using the petrography, major element characteristics and the abundance of the schists to contribute to the unraveling of the petrochemical properties of the area, Northwest of
Obudu Plateau to reconstruct its geologic evolution and development.

\section{Geological Setting}

Northwest Obudu Plateau is geographically located between latitudes $6^{\circ} 45^{\prime}$ and $7^{\circ} \mathrm{OO}$ ' $\mathrm{N}$ and $9^{\circ} \mathrm{OO}$ and $9^{\circ} 16^{\prime} \mathrm{E}$ in the Obudu Basement Complex. This area together with the Oban Massif constitutes the two major basement structures in Southeastern Nigeria (Fig. 1; Owona 2012). These basement spurs are sandwiched between the Congo Craton to the east and West African Craton to the west (Toteu et al., 1987) and extends to the Ahaggar in the north. The area is underlain by migmatitic gneisses, migmatitic schists, granite gneisses, amphibolites and metaquartzites. These metamorphic rocks had been intruded by granites, aplites, dolerites and subordinate occurrences of maficultramafic rocks, ranging from Meso-Neoproterozoic (1400-600 Ma; Owona, 2012), Pan-African (600-500 Ma) (Ekwueme, 2010) and Phanerozoic crustal cover, which have been metamorphosed to at least the uppermost amphibolite facies grade (Ekwueme, 2003; Ukaegbu, 2003). The rocks had undergone tectonic deformation and metamorphism, differentiated and recrystallized to form part of the present Obudu basement complex terrain. 


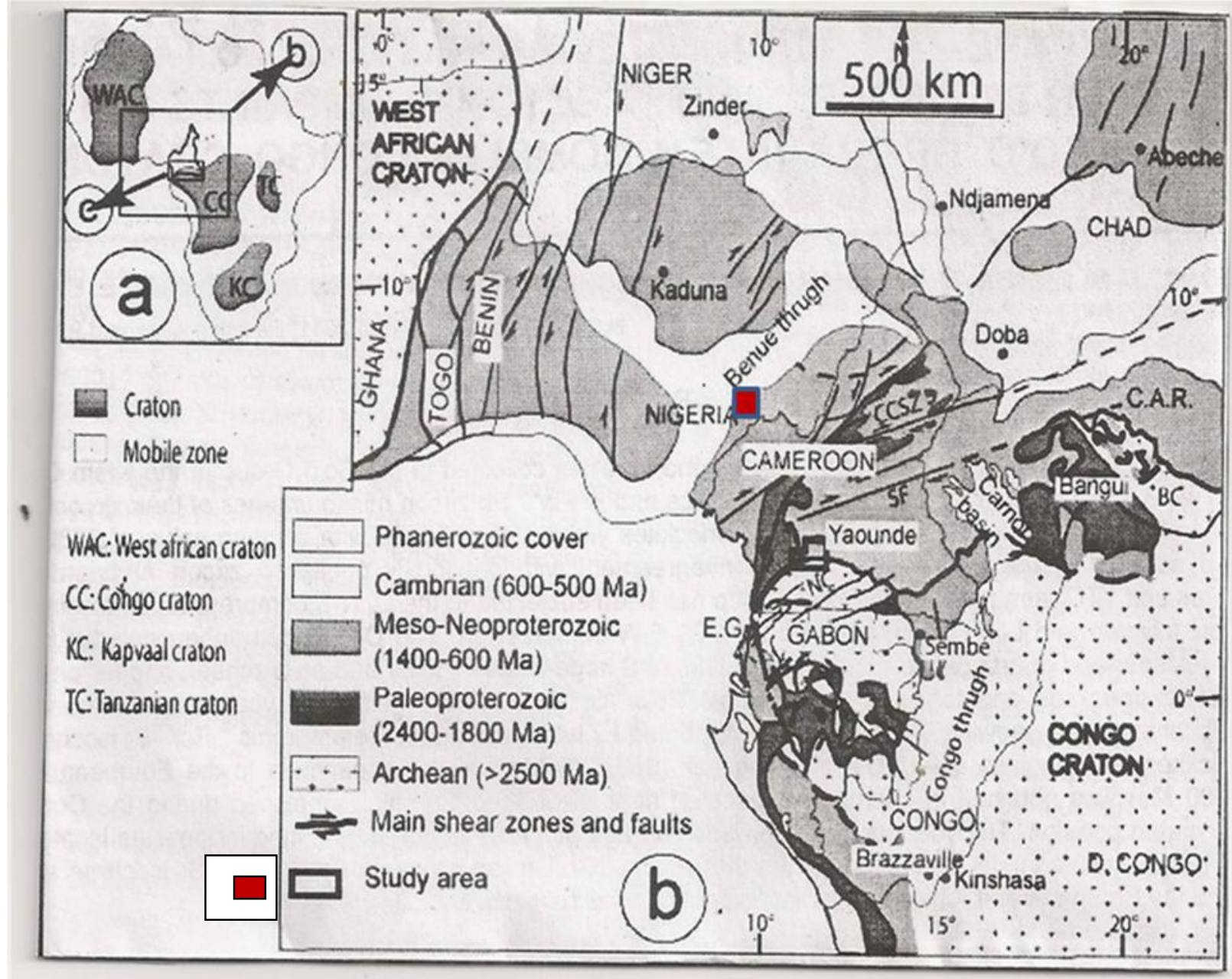

Fig. 1: Generalized geological map showing the Pan-African Belt of Nigeria and the location of the study area in Northwest Obudu Plateau, Southeastern Nigeria (Modified after Owona, et al., 2012)

\section{Field Occurrence and Petrography}

The schists occurring in Northwest Obudu area are mainly migmatitic schists, which include quartz-mica schist (QMS) and garnet- biotite mica schist (GMS), with subordinate occurrence of hornblende schist (HBS) which occurs as unmappable enclave in the gneiss. Fig. 2 shows the field relations of the schists of Northwest Obudu plateau. The schists constitute one of the major rock types occurring in Northwest Obudu area, though subordinate to the migmatitic and granite gneisses.

\section{Migmatitic Schist}

The migmatitic schist (MS) (Fig. 2), occurs around Dura River and Bar-Azov hill, where it is in contact with and overlain by sandstones (Fig. 2). The migmatitic schist consists mostly of the mineral assemblage garnet - biotite - muscovite - quartz. The outcrop of the schist at Dura River channel along Ushongo - Lessel road shows well defined porphyroblastic texture with garnet as porphyroblast set in smaller groundmass composed mainly of biotite, mica flakes and quartz. The mica displays perfect basal cleavage along the (001) planes. The migmatitic schist shows gradational to diffused contacts with the adjacent sandstones. Often the contact is concealed by overburden.

\section{Quartz Mica Schist}

The quartz mica schist (QMS) (Figs. 2), occurs around Mbakeum and Vandeikya areas in Northwest Obudu Plateau. This schist outcrop is fine to medium grained, and shows greenish 




Fig. 2: Geological map of Northwest Obudu Plateau, Southeastern Nigeria 
Table 1: Average modal composition (vol. \%) of Schists of Northwest Obudu Plateau, Southeastern Nigeria.

\begin{tabular}{|c|c|c|c|c|}
\hline Minerals & $\begin{array}{c}\text { MS } \\
\mathrm{n}=5\end{array}$ & $\begin{array}{c}\text { BMS } \\
\mathrm{n}=5\end{array}$ & $\begin{array}{c}\text { QMS } \\
\mathrm{n}=5\end{array}$ & $\begin{array}{c}\mathrm{HBS} \\
\mathrm{n}=3\end{array}$ \\
\hline Quartz & 20 & 21 & 23 & 5 \\
\hline Plagioclase & 30 & 19 & 20 & $\mathrm{Tr}$ \\
\hline Orthoclase & 10 & 11 & 15 & $\mathrm{Tr}$ \\
\hline Biotite & 12 & 20 & 25 & 25 \\
\hline Muscovite & 8 & 16 & 9 & - \\
\hline Garnet & 15 & 11 & 4 & 11 \\
\hline Epidote & 1 & 1 & 1 & - \\
\hline Kyanite & $\mathrm{tr}$ & $\mathrm{Tr}$ & $\mathrm{Tr}$ & - \\
\hline Sillimanite & $\mathrm{tr}$ & $\mathrm{Tr}$ & $\mathrm{Tr}$ & $\mathrm{Tr}$ \\
\hline Chlorite & $\mathrm{Tr}$ & $\mathrm{Tr}$ & $\mathrm{Tr}$ & 2 \\
\hline Hornblende & - & 1 & 2 & 55 \\
\hline Opaques & 4 & - & $\mathrm{Tr}$ & 2 \\
\hline Corundum & - & - & - & - \\
\hline Total & 100 & 100 & 100 & 100 \\
\hline
\end{tabular}

Mineralogical Assemblages:

Qtz + Plag + Orth + Gar + Biot + Musc: Migmatitic schist (MS)

Qtz + Plag + Orth +Gar + Musc + Biot \pm Epdt: Quartz mica schist (QMS) and

Biotite mica schist (BMS),

Hnb +Gar + Biot +Qtz \pm Chlt: Hornblende biotite schist (HBS).

Key; $\mathbf{n}=$ the number of analyses per lithological type.

streak colourations due to the presence of ferromagnesian minerals, or possible retrograde chlorite alteration from biotite, garnet and hornblende. The foliation trends NE -SW $\left(0-30^{\circ}\right)$, with dips mainly in the NW. The rock has been variously intruded by pegmatitic and quartzo-feldspathic veins (Fig. 2), which often truncate the original rock foliation, possibly suggesting the occurrence of late stage magmatic activities in the area and / or an effect of metamorphic remobilization.

\section{Biotite Mica Schist}

The biotite mica schist (BMS) (Figs. 2), crops out in the Dura and Aya River channels, around Lessel and Vandeikya areas of Northwest Obudu Plateau (Fig. 2). The schistosity trends mainly in the NW - SE direction. It occurs mostly as relict enclaves (large boulders) in contact with the migmatitic granite gneiss. Unlike the migmatitic schist which shows gradational to diffused contacts, the biotite mica schist exhibits sharp contact with the host rock (granite Gneiss). The result of the modal analysis of the biotite mica schist (Table 1) shows that it consists of biotite (20 vol. \%), quartz (21 $\%$ ), muscovite (16 vol. \%), plagioclase (19 vol. \%) and garnet $(8 \%)$. Epidote and sillimanite occur in accessory amounts in the BMS.

\section{Hornblende Biotite Schist}

The hornblende biotite schist (HBS) (Figs. 2) is restricted in occurrence. It is found mainly as enclave, closely associated with the migmatitic gneiss in the study area. It shows foliation trending approximately in the NW - SE $\left(0-130^{\circ}\right)$. The result of the modal composition of the HBS is presented in Table 1. The Table shows that the hornblende biotite schist (HBS) is composed dominantly of hornblende (> 55 vol. \%), biotite (25 vol. \%) and garnet (11 vol. \%), quartz (5 vol. $\%)$ while opaques and accessories constitute the rest (Table 1).

\section{Analytical Technique}

Eighteen (18) representative samples of the schists which were collected during the field mapping exercise of Northwest Obudu Plateau were analyzed for their whole rock major element contents using two separate analytical methods: the inductively coupled plasma mass spectrometry (ICP-MS) and inductively coupled plasma emission spectrometry (ICP-ES) techniques, at the Activation Laboratories LTD, Vancouver Canada. The samples for the whole rock geochemistry were prepared by the conventional dressing techniques (Easton, 1972; Ekwueme, 1994; Ofulume, 2009). This 
involved cutting $1 \mathrm{~kg}$ of specimen, crushing and sieving to $80 \%$ passing the 10 meshes. The splitting, pulverizing of specimen, weighing, mixing and digestion of pulp were done by special electronic handling (SEH).

\section{RESULTS AND DISCUSSION}

Schists mapped and analyzed petrographically and by whole rock geochemistry in Northwest Obudu Plateau comprise of migmatitic schist (MS), quartz mica schist (QMS), garnet biotite mica schist (GMS) and hornblende biotite schist (HBS). The results of the modal analysis of the schists are presented in Table 1. The results of the whole rock major elements oxides in weight percent (wt. \%) together with the CIPW and Niggli norms analyses are presented in Table 2. Table 1 shows that the schists consist of average of quartz 5 vol. $\%$ in the HBS, 20 vol. \% in the MS, 23 vol. \% in the BMS, to maximum enrichment of 32 vol. \% in the QMS (Table1). The HBS is depleted in plagioclase and orthoclase, but relatively enriched in biotite and hornblende, 25 and 55 vol. \% respectively.

The MS, QMS and BMS all consist of the mineralogical assemblage quartz - Plagioclase $\left(\mathrm{An}_{32}\right)$ orthoclase - garnet - biotite - sillimanite \pm kyanite (Table 1), indicating that they had attained the uppermost amphibolite facies grade. The result of the whole rock geochemistry (Table 2) shows that all the analyzed schist samples are enriched in silica, with range of $60.11 \mathrm{wt} \%$ in the MS at Bar-Azov hill, 62.94 wt. $\%$ in the BMS at Vandeikya to $66.58 \mathrm{wt} \%$ in the QMS at Dura River, with average of 64.56 wt \% (Table 2). Hence, reflecting the pelitic characteristics of the protoliths of the schists which could be shales and clays (Ekwueme and Onyeagocha 1986; Ekwueme, 1993). The $\mathrm{TiO}_{2}$ concentration shows narrow variation from 0.45 wt \% in the (HBS) to $0.96 \mathrm{wt} \%$ in the MS at Mbakeum
(Table 2). The $\mathrm{Fe}_{2} \mathrm{O}_{3}$ content of the schists vary from low 2.98 wt \% in the quartz mica schist at Dura River along Ushongo - Lessel road (Table 2), to $5.91 \mathrm{wt} \%$ in the MS at Bar- Azov River, with average of $4.57 \mathrm{wt} \%$. The $\mathrm{MgO}$ content varies from $1.09 \mathrm{wt} \%$ in the QMS through 2.26 wt. \% in the BMS to 3.23 wt \% in the HBS (Table 2 ), with average of $2.54 \mathrm{wt} \%$. CaO is depleted in the BMS (2.11 wt \%) and relatively enriched in the HBS (5.10 wt \%) and MS at Mbakeum (4.91 wt. \%), with average of 3.39 wt \% (Table 2). $\mathrm{MnO}, \mathrm{P}_{2} \mathrm{O}_{5}$ and $\mathrm{Cr}_{2} \mathrm{O}_{5}$ are depleted in all the analyzed schist samples, with average values of $0.057,0.22$ and 0.011 wt \% respectively (Table 2 ). The alkalies are variable, but relatively enriched in all the analyzed schist samples, with values of $5.81 \mathrm{wt} \%$ in the HBS rising to $7.36 \mathrm{wt}$ \% in the MS and average of $6.63 \mathrm{wt}$ \% (Table 2), except the $\mathrm{HBS}$ which is relatively depleted in $\mathrm{K}_{2} \mathrm{O}$ with value of 1.52 wt \% (Table 2). Analyses using both the CIPW and Niggli norms of the schists of Northwest Obudu Plateau show that they are all quartz normative and have positive quarzzahl values with Niggli al > alk, which is consistent with their metapelitic character (Ekwueme 2003; Ephraim et al., 2008).

\section{DISCUSSION}

The occurrence of schist belts in the northwestern and southwestern parts of Nigeria had been extensively studied (McCurry, 1976; Rahaman, 1976). Mineralogical, textural and structural properties of schists mapped in Northwest Obudu Plateau show that they share similar characteristics with pelitic metasedimentary rocks reported by Ekwueme and Onyeagocha (1986) in Uwet area of Oban massif of Southeastern Nigeria; Ukaegbu (2003) in southeastern Obudu Massif; Ephraim, (2009) in northeastern Obudu Plateau. Their average $\mathrm{SiO}_{2}$ content is $64.56 \mathrm{wt} \%$, which is within the range of $58-66 \mathrm{wt} \%$ in the Oban 
Table 2: Whole Rock Major Elements Geochemistry (wt. \%), CIPW and Niggli Norms of Schists of Northwest Obudu Area, Southeastern Nigeria.

\begin{tabular}{|c|c|c|c|c|c|c|c|c|}
\hline Oxide & MS & MS & GMS & BMS & QMS & QMS & HBS & $\Sigma N / n$ \\
\hline $\mathrm{SiO}_{2}$ & 64.34 & 60.11 & 65.97 & 62.94 & 66.58 & 68.36 & 63.59 & 64.56 \\
\hline $\mathrm{Al}_{2} \mathrm{O}_{3}$ & 15.87 & 16.46 & 15.42 & 17.13 & 14.99 & 16.36 & 15.31 & 15.53 \\
\hline $\mathrm{TiO}_{2}$ & 0.42 & 0.96 & 0.74 & 0.67 & 0.68 & 0.47 & 0.45 & 0.63 \\
\hline $\mathrm{Fe}_{2} \mathrm{O}_{3}$ & 4.26 & 5.91 & 4.39 & 5.40 & 4.14 & 2.98 & 4.90 & 4.57 \\
\hline $\mathrm{MgO}$ & 3.05 & 3.34 & 2.49 & 2.26 & 2.31 & 1.09 & 3.23 & 2.54 \\
\hline $\mathrm{CaO}$ & 4.91 & 3.20 & 2.66 & 2.11 & 2.56 & 3.16 & 5.10 & 3.39 \\
\hline $\mathrm{MnO}$ & 0.07 & 0.06 & 0.05 & 0.06 & 0.04 & 0.03 & 0.08 & 0.056 \\
\hline $\mathrm{Na}_{2} \mathrm{O}$ & 4.42 & 3.48 & 3.45 & 3.46 & 3.42 & 4.40 & 4.29 & 3.85 \\
\hline $\mathrm{K}_{2} \mathrm{O}$ & 1.54 & 3.88 & 3.50 & 3.66 & 3.45 & 1.92 & 1.52 & 2.78 \\
\hline $\mathrm{P}_{2} \mathrm{O}_{5}$ & 0.20 & 0.61 & 0.25 & 0.13 & 0.22 & 0.08 & 0.20 & 0.24 \\
\hline $\mathrm{Cr}_{2} \mathrm{O}_{5}$ & 0.012 & 0.012 & 0.009 & 0.01 & 0.008 & 0.002 & 0.015 & 0.0097 \\
\hline LOI & 0.70 & 1.40 & 0.70 & 1.7 & 1.2 & 1.0 & 1.10 & 1.114 \\
\hline Total & 99.91 & 99.91 & 99.63 & 99.95 & 99.60 & 99.98 & 99.79 & 99.27 \\
\hline \multicolumn{9}{|c|}{ CIPW Norm of Schists of NW Obudu, SE Nigeria } \\
\hline $\mathrm{Q}(\mathrm{S})$ & 19.4 & 14.28 & 18.9 & 18.3 & 20.6 & 25.1 & 16.2 & 22.5 \\
\hline Or & 9.0 & 27.8 & 20.57 & 22.3 & 20.6 & 11.6 & 9.0 & 16.8 \\
\hline$A b$ & 37.0 & 29.4 & 29.35 & 29.4 & 29 & 37.2 & 36.2 & 32.7 \\
\hline An & 19.18 & 13.6 & 13.07 & 11.0 & 12.5 & 15.0 & 18.1 & 8.4 \\
\hline$C(A)$ & - & 1.8 & 1.12 & 3.8 & 1.0 & 1.5 & - & - \\
\hline $\mathrm{Di}$ & 9.11 & 4.2 & - & 6.0 & - & 6.1 & 8.5 & 6.1 \\
\hline $\mathrm{Hy}$ & - & 4.2 & 13.2 & 5.0 & 12.2 & - & 7.9 & 3.2 \\
\hline $\mathrm{Ol}$ & - & - & - & - & - & - & - & - \\
\hline Mt & - & - & - & - & - & 3.0 & - & - \\
\hline $\mathrm{He}$ & 3.5 & - & - & - & - & - & - & 3.73 \\
\hline II & 0.76 & 2.0 & 1.45 & 1.22 & 1.4 & 1.0 & 1.0 & 1.1 \\
\hline$A p$ & 1.86 & 2.5 & 1.86 & 1.0 & 1.9 & 0.6 & 2.0 & 2.0 \\
\hline \multicolumn{9}{|c|}{ Niggli Norm of Schists of NW Obudu, SE Nigeria } \\
\hline $\mathrm{Al}$ & 41.05 & 42.76 & 37 & 47.98 & 38 & 50.4 & 32 & 44.19 \\
\hline Fm & 20.84 & 25.07 & 29 & 22.28 & 27 & 12.97 & 31 & 21.12 \\
\hline C & 18.96 & 11.85 & 11 & 8.421 & 12 & 13.87 & 19 & 13.74 \\
\hline Alk & 19.15 & 20.33 & 23 & 21.323 & 23 & 22.68 & 18 & 20.99 \\
\hline $\mathrm{Si}$ & 231.88 & 207.67 & 263 & 234.46 & 280 & 280.06 & 223 & 244.31 \\
\hline $\mathrm{Ti}$ & 0.89 & 1.96 & 2.19 & 1.472 & 2.302 & 1.14 & 1.28 & 1.41 \\
\hline $\mathrm{P}$ & 0.31 & 0.89 & 0.49 & 0.205 & 0.512 & 0.14 & 0.43 & 0.39 \\
\hline K & 0.19 & 0.42 & 0.40 & 0.408 & 0.402 & 0.22 & 0.19 & 0.32 \\
\hline $\mathrm{Mg}$ & 0.44 & 0.38 & 0.53 & 0.458 & 0.495 & 0.29 & 0.56 & 0.38 \\
\hline Q & +155 & +126 & +71 & +15 & +88 & $\begin{array}{l}+189 \\
\end{array}$ & +51 & +160 \\
\hline $\mathrm{al}+\mathrm{c}$ & 60.02 & 54.6 & 48 & 56 & 50 & 64.27 & 51 & 57.93 \\
\hline al-c & 22.1 & 30.92 & 26 & 40 & 26 & 36.53 & 13 & 30.45 \\
\hline
\end{tabular}

Key: $M S=$ Migmatitic schist. QMS $=$ Quartz mica schist. GMS $=$ Garnet mica schist. $\mathrm{HBS}=$ Hornblende biotite schist. $\mathrm{Fe}$ as $\mathrm{Fe}_{2} \mathrm{O}_{3}$ total. $\mathrm{Q}(\mathrm{s})=$ quartz, $\mathrm{Or}=$ orthoclase, $\mathrm{Ab}=$ albite, $\mathrm{An}=$ anorthite, $\mathrm{C}(\mathrm{A})=$ corundum, $\mathrm{Di}=$ diopside, $\mathrm{Hy}=$ hypersthene, $\mathrm{Ol}=$ olivine, $\mathrm{Mt}=$ magnetite, $\mathrm{He}=$ hematite, $\mathrm{II}=$ ilmenite, $\mathrm{Ap}=$ apatite; al = Niggli aluminum, $\mathrm{fm}=\mathrm{Niggli}$ ferromagnesian etc. 
$\dagger=$ Migmatitic Schist, Mbakeum

$\square=$ Migmatitic Schist, Aya River

$=$ Hornblende Biotite Schist

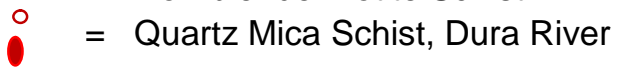

= Quartz Mica Schist, Dura River

$\nabla=$ Biotite Mica Schist, Dura River 2

$\checkmark=$ Garnet Mica Schist

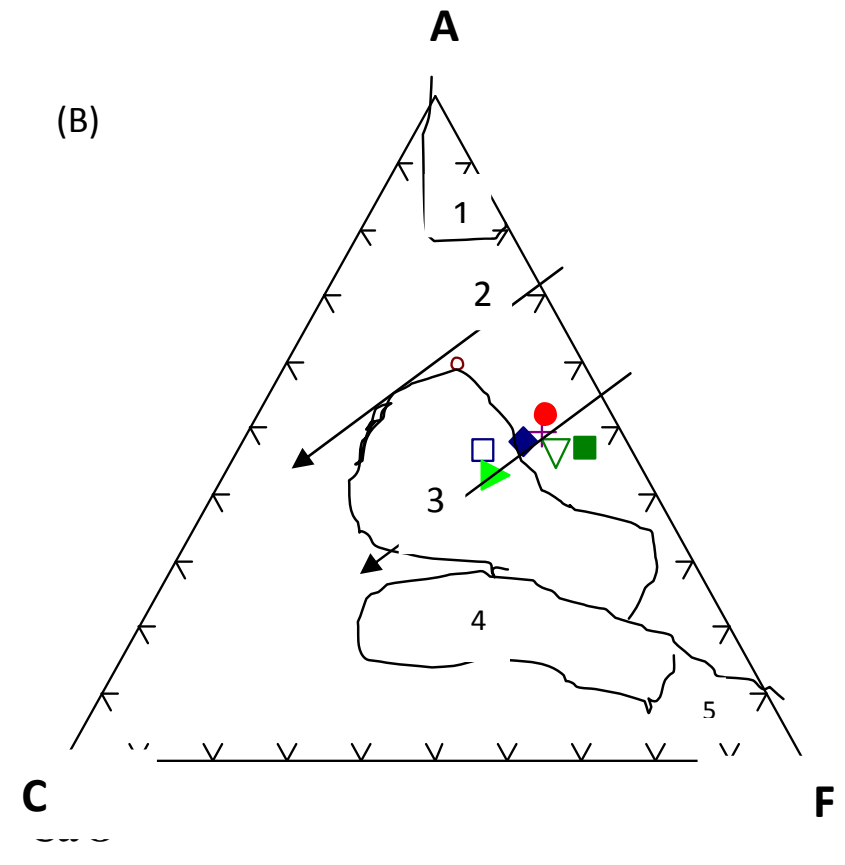

Figs. 4 A - C: Discriminants for petrochemical classification of schists of Northwest Obudu Plateau, Southeastern Nigeria. (A). ACNK vs ANK diagram (Modified after Pearce et al., 1977), (B). ACF diagram (Field specified after Winkler 1967; Ekwueme and Onyeagocha 1986). (C) $\mathrm{SiO}_{2}$ vs $\mathrm{Na}_{2} \mathrm{O}+\mathrm{K}_{2} \mathrm{O}$ diagram (Modified after Pearce et al., 1977). NB: Key remains the same for all the three figures (A), (B) and (C). $1=$ Alrich clays and shales. 2 = Clays and shales either free of carbonate or containing up to $30 \%$ carbonate, between arrows. 3 = Greywackes. $4=$ Basaltic and andesitic rocks. 5 = Ultramafic rocks.

- Obudu areas of Southeastern Nigeria, except one sample of quartz mica schist (migmatitic QMS; Table 2), which has $\mathrm{SiO}_{2}$ content of 68.36 wt \%, possibly indicating quartz-rich specimen from the leucocratic portion of the migmatitic QMS (Table 2).
(A)

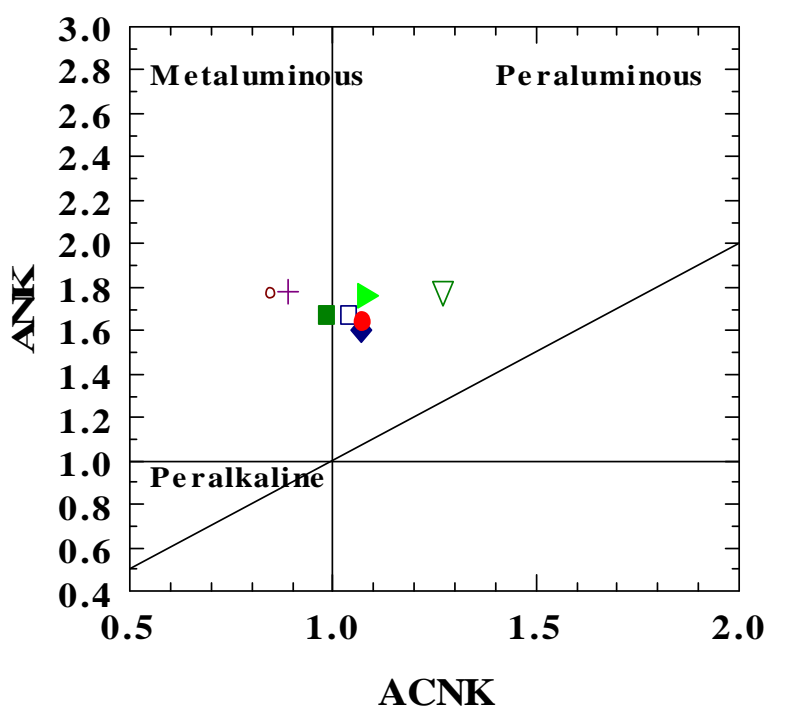

(C)

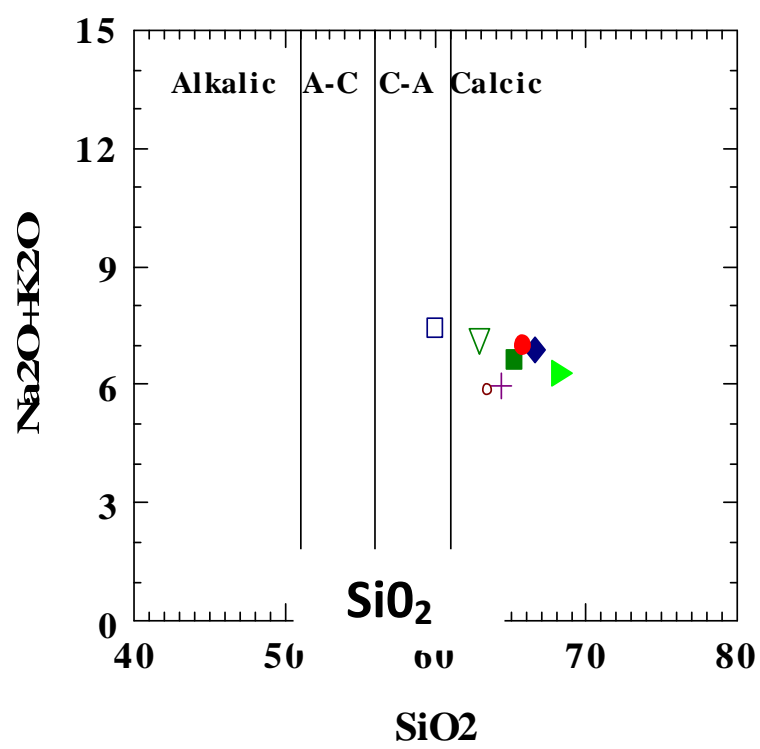

This high enrichment in of $\mathrm{SiO}_{2}$ might possibly be a result of the post metamorphic granitic and / or pegmatitic intrusions into the schist belts, and the late stage formation of quartz vein in the area. The $\mathrm{Al}_{2} \mathrm{O}_{3}$, $\mathrm{MgO}$ and alkali content are moderate to high, with the $\mathrm{K}_{2} \mathrm{O}>\mathrm{Na}_{2} \mathrm{O}$ contents in most of the samples, which is consistent with properties of rocks of crustal pelitic derivation (Ekwueme 2003). The mineral assemblage quartz - garnet - Plagioclase $\left(A n_{32}\right)$ - sillimanite \pm hornblende coexist in the schists indicating that the schists were affected by the Pan-African tectonothermal event.

However, the alkali content of the present study shows variable characteristics. For example the $\mathrm{K}_{2} \mathrm{O}$ shows superior abundance over the $\mathrm{Na}_{2} \mathrm{O}$ in the $\mathrm{MS}$ at Aya River, GMS, BMS, and QMS, which is consistent with the property of rocks of metapelitic character 
(Ekwueme, 1993). Conversely, the absolute concentration of $\mathrm{Na}_{2} \mathrm{O}>\mathrm{K}_{2} \mathrm{O}$, in the MS at Mbakeum, QMS at Dura River and HBS (Table2), point to two possibilities: either that these rocks had been contaminated by an intruding basaltic magma from mantle source, or that the area had undergone metasomatic reaction in which the potash was preferentially leached away relative to the soda.

The schists show dominant foliation trend in the $\mathrm{N}-\mathrm{S}, \mathrm{NE}-\mathrm{SW}\left(0-30^{\circ}\right)$, with minor trends in NW - SE $\left(0-130^{\circ}\right)$ and $E-W$ directions, which are in agreement with trends reported by Ekwueme (2010) in metamorphosed rocks of Obudu and Oban basement areas of Southeastern Nigeria, and by Ephraim (2009) in the basement rocks of Northeast Obudu Massif. Plots of geochemical data of the schists in a discrimination diagram, ACNK versus ANK (Fig. 4 A) after Pearce (1977) and Manier and Piccolo (1989), show that $63 \%$ of the schists plot in the peraluminous field, while $37 \%$ plot in the metaluminous field. This indicates that the schists of Northwest Obudu Plateau are mostly peraluminous metasediments with little contribution from metaluminous parentage. This distribution is consistent with the molecular proportion of $\mathrm{Al}_{2} \mathrm{O}_{3}>\left(\mathrm{CaO}+\mathrm{Na}_{2} \mathrm{O}+\right.$ $\mathrm{K}_{2} \mathrm{O}$ ), thus corroborating their peraluminous character. The average composition of the analysed schists (Table 2 ), when plotted in the ACF diagram (Fig. 4 B), more than $62.5 \%$ of the analyzed samples plot in the field $2 \mathrm{~b}$ (between arrows) of Winkler (1967) and Ekwueme and Onyeagocha (1986), indicating shales and clays containing about $30 \%$ carbonates; $25 \%$ plot in the field 3 (Wyoming greywackes), while only one sample plots in the field 2 (carbonate free mud rocks) (Fig. 4 B). This trend of distribution is consistent with the report of Ekwueme and Onyeagocha (1986) in the metasedimentary schists of Oban area of Southeastern Nigeria. The schists of Northwest Obudu area are metasediments possibly derived from clays and shales which could have been contaminated by other crustal rocks.

\section{CONCLUSION}

Schists in Northwest Obudu Plateau have been distinguished into four: migmatitic schist (MS), quartz mica schist (QMS), garnet biotite mica schist (GMS) and hornblende biotite schist (HBS). The schists are associated with migmatitic and granite gneisses and intruded by granites and quartzo-feldspathic veins of various sizes and orientations. The area is flanked to northwest bordering the Benue Trough by Cretaceous sediments (mainly sandstones). The schists show foliation trending dominantly in the $\mathrm{N}$ - S to NE - SW $(0-$ $35^{\circ}$ ), indicating effect of Pan-African tectonothermal event. Mineralogical assemblage of quartz - garnet Plagioclase $\left(A n_{32}\right)$ - sillimanite \pm hornblende indicates that the schists had been metamorphosed at least up to the uppermost amphibolite facies grade. Plots in discrimination diagrams show that the schists are of peraluminous pelitic origin.

\section{ACKNOWLEDGEMENT}

We acknowledge the assistance of Mr. E. U. Ayara, and Mr. A. O. Ndaw both of the Nigerian
Geological Survey Agency and Dr E. E. Ukwang of the Department of Geology University of Calabar Nigeria, for their assistance during the field geological mapping exercise. OYE is indebted to the Management of the Federal University of Technology, Owerri (FUTO), for granting him a PhD study fellowship to undertake his $\mathrm{PhD}$ study at the University of Calabar. This paper is a part of the contribution from the $\mathrm{PhD}$ Thesis.

\section{REFERENCES}

Beltaro, F., 1962. Preliminary report of the mapping of the basement complex of sheet No. 73 Ogoja Province. Geological Society of Nigeria, Report 1450, 13.

Easton, A. J., 1972. Chemical Analyses of Silicate Rocks. Amsterdam: Elsevier Sciences, 257p.

Ejimofor, O. C., Umeji, A. C. and Turaki, U. M., 1996. Petrography and major elements geochemistry of basement rocks of Northern Obudu area, Eastern Nigeria. J. Min. Geol. 32 (1): 1 - 9.

Ekwueme, B. N., 1983. Regional Metamorphism of pelitic rocks of Lokoja, Nigeria. J. Geol. 20: 71-77.

Ekwueme, B. N., 1994. Elementary Crystallography and Mineralogy including Optics. University of Calabar Press. 242p.

Ekwueme, B. N., 1998. Geochemistry of Precambrian gneisses in Obudu Plateau, S. E. Nigeria. Global J. Pure \& Appli. Sci. 4 (3), 277 - 282.

Ekwueme, B. N., 2003. Precambrian Geology and evolution of the Southeastern Nigeria Basement Complex. University of Calabar Press, $135 \mathrm{p}$.

Ekwueme, B. N., 2010. The Pan African Tectonothermal Event of Southeastern Nigeria - A Review. Nigerian Min. Geosci. Soc. Calabar-2010, Abstract Vol. p.3.

Ekwueme, B. N. and Bassey, E. E., 2005. Rare earth element geochemistry and protoliths of schists in Southeast Lokoja, central Nigeria. Global J. Geol. Sci., 3(1): p. 9-15.

Ekwueme, B. N. and Kroner, A., 1997. Zircon evaporation ages and chemical composition of migmatitic schist in the Obudu Plateau: Evidence of Paleo-Proterozoic (Ca. 1769Ma) component in the Basement Complex of Southeastern Nigeria. J. Min. Geol. 33: 81- 88.

Ekwueme, B. N. and Onyeagocha, A. C., 1986. Geochemistry of metasedimentary rocks of Uwet area, Oban Massif, Southeastern Nigeria. Geol. Rundsch. 75, $411-420$.

Ephraim, B. E., 2005. Petrology and geochemistry of Basement rocks, northeast Obudu Plateau, 
Bamenda massif, S. E. Nigeria. Unpublished Ph.D. Thesis, University of Calabar, Nigeria. $358 \mathrm{p}$.

Ephraim, B. E., 2009. Petrochemistry and Petrogenesis of granite gneiss of northeast Obudu Bamenda Massif, Southeastern Nigeria. J. Min. Geol. 2009, p. $59-71$.

Ephraim, B. E., Ekwueme, B. N., Moazzen, M. and Modjarrad, M., 2008. P-T condition of Pan-African Orogeny in SE Nigeria. Central European Geology, 51 (4): 359-78.

Irvine, T. N. and Baragar, R. A., 1971. A guide to the chemical classification of the common volcanic rocks. Canadian J. Earth Sci., 8: 523-548.

Manier, P. D. and Piccoli, P. M., 1989. Tectonic discrimination of granitoids. Geol. Soc. Am. Bull. 101: $635-643$.

Obioha, Y. E. and Ekwueme, B. N., 2011. Petrology and chemical composition of gneisses of Northwest Obudu Plateau, Southeastern Nigeria. Global J. Pure and Appli Sciences, 17 (2), p. 215 - 226.

McCurry, P., 1976. The geology of the Precambrian to lower Paleozoic rocks of northern Nigeria - a review. In: Gerlogy of Nigeria. Ed. Kogbe, C. A. (Elizabethan Pub.Co. Lagos, Nigeria), 15 - 39

Ofulume, A. B., 2009. Keys of Mineralogy, $2^{\text {nd }}$. Edn. Dikes Memorial Bookshop Limited, Port Harcourt. 162p.

Orajaka, S. O., 1964. Geology of the Obudu area, Ogoja Province, Eastern Nigeria. Le Naturaliste Canadian. XCL (3): 73-78.

Orajaka., 1971. The Petrogenesis of the Obudu-Type Enderbite. Journal of Mines, Metals and Fuels (Calcutta), p.94- 98.
Owona, S., Ondoa, J. M., Tichomirowa, M., Ratschbacher, L., Tchoua., F. M. and Ekodeck., G. E., 2012. New207Pb/206Pb-Zr Minimum Evaporation, Metamorphic 87Rb/86Rb-WR-Bt Ages and Tectonic imprints in the Archaean S0'0 Group (Ntem Complex/Congo Craton, Sw. Cameroon. Global J. Geol. Sci. 10 (1): 37 - 46.

Pearce, T. H., Gorman, B. E. and Birket, T. C., 1977. The relationship between major element chemistry and tectonic environment of basic and intermediate volcanic rocks. Earth Planetary Sci. letter, 36:121 - 132.

Rahaman, M. A., 1976. Progressive polyphase metamorphism in pelitic schists around Aiyetoro, Oyo State, Nigeria. J. Min. Geol. 12 (2), 33 344.

Toteu, S. F., Michard, A., Bertrand, J. M. and Rocci, G., 1987. Precambrian rocks from northern Cameroun, Orogenic evolution and chronology of Pan African Belt of Central Africa. Precambrian Res. 37: 71-81.

Ukaegbu, V. U., 2003. The petrology and geochemistry of parts Obudu Plateau, Bamenda Massif, Southeastern Nigeria. Unpublished Ph. D. Thesis, University of Port Harcourt, Nigeria.

Ukaegbu, V. U. and Beka, F. T., 2007. Petrochemistry and geotectonic significance of EnderbiteCharnockite association in the Pan-African Obudu Plateau, Southeastern Nigeria. J. Min. Geol, 43:1, 1-14.

Ukwang, E. E., 2007. Petrochemistry and Geochronology of the Area Southwest of Obudu Southeastern Nigeria. Unpublished PhD. Thesis, University of Calabar, Calabar Nigeria. 193p.

Winkler, H. G. F., 1967. Petrogenesis of morphic rocks. 2nd Ed., Springer-Verlag, New York, $237 p$. 